Article

\title{
Biochemical Characterization of Traditional Varieties of Apricots (Prunus armeniaca L.) of the Campania Region, Southern Italy
}

\author{
Florinda Fratianni ${ }^{1} \mathbb{D}$, Antonio d'Acierno ${ }^{1, *}$, Donatella Albanese ${ }^{2} \mathbb{D}$, Marisa Di Matteo ${ }^{2}$, Raffaele Coppola ${ }^{1,3}{ }^{\mathbb{D}}$ \\ and Filomena Nazzaro ${ }^{1}$ (D) \\ 1 Institute of Food Science, CNR-ISA, Via Roma 64, 83100 Avellino, Italy; florinda.fratianni@isa.cnr.it (F.F.); \\ coppola@unimol.it (R.C.); filomena.nazzaro@isa.cnr.it (F.N.) \\ 2 Department of Industrial Engineering, University of Salerno, Via Giovanni Paolo II, 84084 Fisciano, Italy; \\ dalbanese@unisa.it (D.A.); mdimatteo@unisa.it (M.D.M.) \\ 3 Department of Agriculture, Environment and Food, University of Molise, Via de Sanctis Snc, \\ 86100 Campobasso, Italy \\ * Correspondence: dacierno.a@isa.cnr.it; Tel.: +39-0825299509
}

\section{check for}

updates

Citation: Fratianni, F.; d'Acierno, A.; Albanese, D.; Matteo, M.D.; Coppola,

R.; Nazzaro, F. Biochemical Characterization of Traditional Varieties of Apricots (Prunus armeniaca L.) of the Campania Region, Southern Italy. Foods 2022, 11, 100.

https://doi.org/10.3390/

foods11010100

Academic Editor: Severino Matias De Alencara

Received: 12 November 2021 Accepted: 29 December 2021 Published: 31 December 2021

Publisher's Note: MDPI stays neutral with regard to jurisdictional claims in published maps and institutional affiliations.

Copyright: (C) 2021 by the authors. Licensee MDPI, Basel, Switzerland. This article is an open access article distributed under the terms and conditions of the Creative Commons Attribution (CC BY) license (https:// creativecommons.org/licenses/by/ $4.0 /)$
Abstract: Campania is the most important region of Italy in the apricot cultivation, present mostly in the Vesuvio area. At least to the best of our knowledge, no studies are reporting the biochemical characterization of the considerable number of traditional apricot varieties present on this territory, including the qualitative and quantitative profile of the polyphenols present. Our work evaluated the content of $\beta$-carotene, total phenolics, phenolic profiles, ascorbic acid and antioxidant activity of 23 traditional varieties of apricots of the Campania region. Principal component analysis (PCA) highlighted that, in the two main groups, the antioxidant activity was strongly affected by the content of ascorbic acid (-0.89), or slightly affected by the content of total polyphenols $(-0.67)$, respect to the content of ascorbic acid ( -0.55$)$, never by $\beta$-carotene. Chlorogenic acid (up to $55.07 \mu \mathrm{g} \mathrm{g}^{-1}$ ) and catechin (up to $96.15 \mathrm{\mu g} \mathrm{g}^{-1}$ ) resulted the most abundant polyphenols recognized through the chromatographic analysis. PCA, extended to the polyphenol profile, confirmed the distribution of the varieties in two large groups, evidencing once again the hierarchical distance of four varieties ("Panzona", "Paolona" "Baracca" and "Boccucia Eboli") compared to the others.

Keywords: apricot; polyphenols; antioxidant; biodiversity

\section{Introduction}

Apricot (Prunus armeniaca L.) is one of the most important fruits produced in temperate countries. The typical apricot grows in geographically diverse areas ranging from the Siberia cold winters to North Africa, characterized by a subtropical climate of North Africa and from the desert Central Asia to Japan and Eastern China [1]. Its total world production moves to about 2.6 million tons. Uzbekistan and Turkey are the leading countries in the production of apricot fresh fruits [www.fao.org/faostat/en/\#data/QC. accessed on 10 November 2021] and mainly Turkey, for the manufacturing of dried apricots [2]. Italy is the fifth worldwide and the first European producer of apricots, with 222,690 tons [www.fao.org/faostat/en/\#data/QC. accessed on 10 November 2021]. In Italy, the production of apricots is concentrated primarily in Campania, and Emilia-Romagna [3]. Campania is the most important region of Italy in the apricot cultivation, with about 50,000 tons of product, present mainly in the Vesuvio area, which represents around $80 \%$ of the regional production. In this area, there are about 2000 hectares of apricots field, with a production that, in normal climate conditions, should be settled around 400,000 quintals, mostly consumed as fresh fruit.

A certain portion-variable from year to year- is transformed into nectars, i.e., juice and pulp, while a small part is transformed to give jams, dried and candied, and ultimately 
a minimal portion is transformed into frozen, and canned products (http: / /agricoltura. regione.campania.it/tipici/albicocca.htm. accessed on 7 July 2021). Climate conditions and variety influence the growth and ripening of the fruit. The fruit has the shape of a drupe, similar to a plum, with a thin outer skin walling the yellow flesh. It has several shades of color ranging from yellow to orange with a reddish random overlay, seen as parameters affecting its quality $[4,5]$. Apricot-consumed both as fresh and dried-is thus an important component of the human diet. Its main phytochemicals possess well-known biological properties, comprising antioxidant [6,7], anti-microbial [8], and anti-inflammatory [9].

The importance of apricot and by products for the human health is well ascertained. In fact, it can exert different positive effects against such as cancer, cardiovascular disease, atherosclerosis and those diseases related to the aging. Furthermore, it can have protective effect on kidney and liver [10].

Apricot contains several secondary metabolites [11-13], many of them being active as antioxidants [14]. Polyphenols and carotenoids (mainly $\beta$-carotene) represent the most abundant classes of phytochemicals contained in this fruit [15]; such molecules are not only crucial for the antioxidant activity but play a primary role also in the color and taste in fruit [4]. In addition, apricots contain a substantial amount of ascorbic acid. Due to the wide range of existing varieties, identifying the best genotypes assumes particular importance for both breeders and consumers, which can select and consume those specific products with high nutritional quality, respectively. Therefore, the present study focused on the following aims:

To analyze the content of $\beta$-carotene, total phenolics, phenolic profiles, ascorbic acid of different traditional landraces of apricots of the Campania region, Southern Italy.

To determine the in vitro antioxidant activity by the DPPH radical-scavenging activity.

To correlate the antioxidant activity of the landraces to total phenolics, ascorbic acid, and carotenoids aimed to identify the principal factors affecting the antioxidant properties of the products.

Principal component analysis (PCA) investigated the interrelationships between these parameters and the different varieties.

\section{Materials and Methods}

\subsection{Chemicals}

The Folin-Ciocalteu reagent was purchased from BIO-RAD (Milano, Italy). Chlorogenic, gallic, caffeic, ferulic, $p$-coumaric acids, epicatechin, rutin, quercetin, 2,2-diphenyl-1picrylhydrazyl (DPPH), ascorbic acid, $\beta$-carotene, HPLC-grade methanol, metaphosphoric, sulphuric, formic and acetic and acids, acetonitrile, petroleum ether, ethanol and acetone were acquired from Sigma-Aldrich (Milano, Italy). Apigenin was bought from Extrasynthese (Genay, France). Distilled water was obtained from a Milli-Q apparatus (Millipore, Milano, Italy).

\subsection{Plant Material}

Plant material included 23 varieties of apricot (Prunus armeniaca L.), "Baracca"; "Boccuccia Eboli"; "Boccuccia Grossa"; "Boccuccia Liscia";"Campana”; "Diavola"; “Fracasso"; "Fronne Fresche"; “Lisandrina”; “Magnolona”; "Montedoro"; “Nonno"; "Panzona"; “Paolo na"; "Pazza"; "Puzo"; "San Francesco"; "Scassulillo"; "Scassulillo Grande";"Signora"; "Zeppona"; "Pollastrella"; "Boccuccia Spinosa" listed by the Official Bulletin of the Campania Region (B.U.R.C. n. 42, 145, 2009), grown and collected during the month of June 2011 in the experimental plant "Improsta" located in Eboli (SA), of the Campania region, Italy $\left(40.5569^{\circ} \mathrm{N}, 14.9832^{\circ} \mathrm{E}\right)$, characterized by a Mediterranean climate by an average of air temperature $(\mathrm{T})=23.9^{\circ} \mathrm{C}$, humidity $(\mathrm{U})=64.9 \%$, wind $(\mathrm{W})=8.1 \mathrm{~km} / \mathrm{h}$, rainy days $(\mathrm{R})$ $=6$ (https: $/ /$ www.ilmeteo.it $/$ portale $/$ archivio-meteo $/$ Eboli $/ 2011 /$ Giugno. accessed on 10 November 2021) during the growing season.

As control we used another variety of apricot: "Tipo 35". Fruits were harvested at the physiological maturity (ready-to-eat), visually when the fruits were $80 \%$ yellow color on 
the surface, and immediately transported to the laboratory. Herein, $0.5 \mathrm{~kg}$ for each variety were well mixed to obtain three independent replicates and stored at $-26{ }^{\circ} \mathrm{C}$ before the analysis. All the analysis were made in triplicate.

\subsection{Dosage of Ascorbic Acid}

Samples were cut, pressed, and kept into the dark for $1 \mathrm{~h}$ at $4{ }^{\circ} \mathrm{C}$ in three volumes of metaphosphoric acid (4\%) following the method of Nazzaro et al. [16]. Then, they were centrifuged $\left(11,600 \times \mathrm{g}\right.$ for $10 \mathrm{~min}$ at $4{ }^{\circ} \mathrm{C}$, Biofuge, Beckman Italia, Cassina de' Pecchi, Milano, Italy); the supernatant was collected after filtration $(0.45 \mu \mathrm{m}$ mesh, Millipore, Milano, Italy). The dosage of ascorbic acid was performed by HPLC-UV (Gold System, Beckman Italia, Cascina dè Pecchi, MI, Italy) using a Khromasil KR 100-5 C18 column $(25 \mathrm{~cm} \times 4.6 \mathrm{~mm})$. The run was performed at room temperature, at the following analytical conditions: mobile phase $=$ HPLC-grade water acidified with sulphuric acid $0.001 \mathrm{M}$; flow rate: $1.0 \mathrm{~mL} \mathrm{~min}^{-1}$; detection wavelength $=245 \mathrm{~nm}$; injection volume $=20 \mu \mathrm{L}$. The standard curve was obtained using ascorbic acid dispersed in the mobile phase. Results were indicated as $\mathrm{mg} 100 \mathrm{~g}^{-1}$ of fresh sample.

\subsection{Carotene Content}

Samples were cut and pressed in ethanol (1:1 w/v); subsequently we included petroleum ether $(1.5: 1 v / v)$ [17]. Mix was robustly agitated and centrifuged $(11,600 \times g, 15 \mathrm{~min}$; Biofuge, Beckman Italia), then we recuperated the supernatant. The steps were repeated up until the absolute loss of the color, and the supernatants were put jointly. The amount of carotenoids was assessed at $\lambda: 450 \mathrm{~nm}$ (Cary $50 \mathrm{Uv} /$ Vis Varian-Agilent Italia, Cernusco sul Naviglio, Italy) utilizing petroleum ether as blank, and considering $\varepsilon=2592$ as the extinction coefficient. Results were indicated as mg of $\beta$-carotene $100 \mathrm{~g}^{-1}$ of fresh sample.

\subsection{Total Polyphenols}

Samples were cut and pressed (1:3 w/v) in acidified methanol (acetic acid 1\%); subsequently, they were kept overnight at $4{ }^{\circ} \mathrm{C}$ [18]. Supernatants were collected after centrifugation (11,600× g, 15 min; Biofuge, Beckman Italia). The total polyphenols content was assessed (Cary 50 Varian-Agilent) at $\lambda=760 \mathrm{~nm}$, following the method of Singleton and Rossi [19]. Gallic acid was used to generate the standard curve. Results were expressed in terms of $\mathrm{mg}$ gallic acid equivalent $100 \mathrm{~g}^{-1}$ of fresh sample.

\subsection{Antioxidant Activity}

Samples were cut and pressed $(1: 3 w / v)$ in an acidized solution of methanol (containing acetic acid 1\%); then, they were kept overnight at $4{ }^{\circ} \mathrm{C} \pm$ [18]. Supernatants were recovered by centrifugation $(11,600 \times g, 15 \mathrm{~min}$; Biofuge, Beckman). The stable radical 2,2-diphenyl1-picrylhydrazyl (DPPH assay) was used to evaluate the radical-scavenging activity of our samples [20]. The analysis was achieved in microplates. $15 \mu \mathrm{L}$ of extract were added to $300 \mu \mathrm{L}$ of a solution of methanol-DPPH $\left(6 \times 10^{-5} \mathrm{M}\right)$. The absorbance was measured at $\lambda=517 \mathrm{~nm}$ (Cary 50 MPR Varian-Agilent). The EC50 indicated the amount of sample amount (as $\mathrm{mg}$ ) required to inhibit, after $60 \mathrm{~min}$ of incubation, the activity of $1 \mathrm{~mL}$ of the DPPH by $50 \%$.

\subsection{Chromatographic Analysis}

Polyphenol profile of the different cultivars of apricot was evaluated by ultra-highperformance liquid chromatography (UPLC) analysis using the ACQUITY Ultra Performance LC $^{\text {TM }}$ system (Waters, Milford, MA, USA) connected to a PDA 2996 photodiode array detector (Waters). The connected Empower software (Waters) allowed the control of the instruments and the acquisition and processing of the relative data. The analysis was performed following the methods described by Pane et al. [21]. Extracts and standards were dispersed in methanol; then they were filtered using microfilter units Whatman $0.45 \mu \mathrm{m}$ (Waters, Milford, MA, USA). Running conditions = Injection volume: $5 \mu \mathrm{L}$. Mobile phase: solvent A (7.5 mMol acetic acid) and solvent B (acetonitrile); flow rate: $250 \mu \mathrm{L} \mathrm{min}^{-1}$; 
column: reversed-phase column (BEH C18, $1.7 \mu \mathrm{m}, 2.1 \times 100 \mathrm{~mm}$ Waters); temperature: $30{ }^{\circ} \mathrm{C}$. Each analysis was performed with a gradient elution $(0.8 \mathrm{~min}: 5 \%$ B for; $5.2 \mathrm{~min}$ : from 5\% to $20 \% \mathrm{~B} ; 0.5 \mathrm{~min}$ : $20 \% \mathrm{~B} ; 1 \mathrm{~min}$ : from 20 to $30 \% \mathrm{~B} ; 0.2 \mathrm{~min}$ : $30 \% \mathrm{~B} ; 2.3 \mathrm{~min}$ : from $30 \%$ to $50 \% \mathrm{~B} ; 1 \mathrm{~min}$ : from $50 \%$ to $100 \% \mathrm{~B} ; 1 \mathrm{~min}: 100 \% \mathrm{~B} ; 0.5 \mathrm{~min}$ to reach $5 \% \mathrm{~B}$ from $100 \%$ B. Then, the column was restored to the initial conditions for $2.5 \mathrm{~min}$. Quantification of polyphenols were made based on linear curves of the standards.

\subsection{Statistical Analysis}

Data were expressed as mean \pm standard deviation of triplicate measurements. Calculations were performed through the PC software "Excel Statistics". Principal component analysis (PCA) was used to evaluate the interrelationships between the biochemical parameters and the different varieties, following Fratianni et al. [19] through the software package MATLAB.

\section{Results and Discussion}

Apricot is source of several important secondary metabolites, in particular polyphenols, $\beta$-carotene and ascorbic acid. Thus, this fruit is also font of antioxidants. We have determined the content of such metabolites, and the antioxidant activity, of different traditional varieties of apricots present in the territory of the Campania region. The content of ascorbic acid, b-carotene and total polyphenols was expressed as mg 100 of fresh weight, following Wani et al. (2017) [22]. Results are shown in Table 1.

\subsection{Ascorbic Acid Content}

The quantity of ascorbic acid found in the apricot varieties analyzed varied between $3.47 \mathrm{mg}$ ("Signora") and $10.08 \mathrm{mg}$ in $100 \mathrm{gr}$ of the fresh product ("Magnolona"). Some of them ("Magnolona", "Scassulillo grande ", "Boccuccia spinosa", "Fracasso") presented content of ascorbic acid close to those exhibited by other varieties analyzed by Ishaq et al. [23]. Many of them contained an amount of ascorbic acid superior to that present in the apricot "tipo 35" used as control; for some of them, the content of ascorbic acid was double ("Scassulillo" "Lisandrina") or more than double ("Boccuccia Spinosa", "Fracasso", "Magnolona", and "Scassulillo grande") compared with that showed the control. All the varieties had a vitamin C content similar to that found by Hegedus et al. [24], but inferior, although in some varieties, such as "Magnolona", "Scassulillo grande" and "Fracasso" just slightly less, than those reported by Akin et al. [25], which, in 11 apricot varieties of Malatya (Turkey), known as "the city of apricots", found a vitamin C content of $11.5 \mathrm{mg} 100 \mathrm{~g}^{-1}$, if calculated based on the fresh weight. The presence of ascorbic acid is an essential factor not only for the beneficial effects that such molecule can exert on health but also for applications relating to the food industry, since it is attributed to the ascorbic acid a role in inhibiting the action of polyphenol oxidases and therefore in delaying the browning of the fruits [26]. The amount of ascorbic acid was higher than those reported by Cui et al. 2019 [27], and, for the majority of the cultivars analyzed by us, greater than those reported by Wani et al. [28], and Kafkaledou [29], which observed in eight apricot cultivars a content never higher than $0.987 \mathrm{mg} 100 \mathrm{~g}^{-1}$ of product. Our data resulted in higher also respect to those indicated by Nourozi and Sayyari [30], about the variety Nouri that never exceeded $2.4 \mathrm{mg} \mathrm{kg}^{-1}$ of fresh product. Within the cultivars we analyzed, it is to highlight the different behavior exhibited by the 4 varieties "Boccuccia", which content of ascorbic acid ranged between $4.09 \mathrm{mg} \mathrm{mg} 100 \mathrm{~g}^{-1}$ of fresh product ("Boccuccia grossa") to more the double ( $9.80 \mathrm{mg} / 100 \mathrm{~g}$ of the fresh product, variety "Boccuccia spinosa"). The significant difference in ascorbic acid, as well as that reported for the other parameters evaluated (see below) among the apricot varieties observed in our study, in this case could be mostly attributed to the influences of factors such genotypic differences more than the year of collection and the period of maturity [22]. 
Table 1. Content of ascorbic acid, $\beta$-carotene, total polyphenols and antioxidant activity exhibited by the traditional varieties of apricots of the Campania region. Data represent the average $( \pm S D)$ of three independent experiments. FW: fresh weight.

\begin{tabular}{|c|c|c|c|c|}
\hline Varieties & $\begin{array}{c}\text { Ascorbic Acid } \\
\left(\mathrm{mg} 100 \mathrm{~g}^{-1} \mathrm{FW}\right)\end{array}$ & $\begin{array}{c}\beta \text {-Carotene } \\
\left(\mathrm{mg} 100 \mathrm{~g}^{-1} \mathrm{FW}\right)\end{array}$ & $\begin{array}{c}\text { Total } \\
\text { Polyphenols } \\
\left(\mathrm{mg} 100 \mathrm{~g}^{-1} \mathrm{FW}\right)\end{array}$ & $\begin{array}{c}\text { Antioxidant } \\
\text { Activity } \\
\text { (EC50, mg) }\end{array}$ \\
\hline BARACCA & $4.05( \pm 0.13)$ & $0.408( \pm 0.52)$ & $29.88( \pm 11.382)$ & $10.15( \pm 0.04)$ \\
\hline BOCCUCCIA EBOLI & $6.04( \pm 0.09)$ & $0.307( \pm 0.68)$ & $35.87( \pm 15.29)$ & $6.60( \pm 0.12)$ \\
\hline BOCCUCCIA GROSSA & $4.09( \pm 0.15)$ & $0.223( \pm 0.26)$ & $22.130( \pm 19.87)$ & $12.79( \pm 0.16)$ \\
\hline $\begin{array}{l}\text { BOCCUCCIA } \\
\text { LISCIA }\end{array}$ & $7.73( \pm 0.36)$ & $0.235( \pm 0.28)$ & $22.38( \pm 12.57)$ & $11.18( \pm 0.11)$ \\
\hline $\begin{array}{l}\text { BOCCUCCIA } \\
\text { SPINOSA }\end{array}$ & $9.80( \pm 0.21)$ & $0.134( \pm 0.04)$ & $22.020( \pm 9.32)$ & $9.32( \pm 0.15)$ \\
\hline CAMPANA & $5.72( \pm 0.22)$ & $0.134( \pm 0.06)$ & $19.96( \pm 10.67)$ & $7.46( \pm 0.07)$ \\
\hline DIAVOLA & $3.58( \pm 0.38)$ & $0.126( \pm 0.03)$ & $16.728( \pm 1.82)$ & $11.49( \pm 0.10)$ \\
\hline FRACASSO & $9.27( \pm 0.21)$ & $0.088( \pm 0.02)$ & $20.168( \pm 8.43)$ & $8.96( \pm 0.15)$ \\
\hline $\begin{array}{l}\text { FRONNE } \\
\text { FRESCHE }\end{array}$ & $4.07( \pm 0.10)$ & $0.100( \pm 0.04)$ & $9.952( \pm 3.31)$ & $11.54( \pm 0.20)$ \\
\hline LISANDRINA & $8.79( \pm 0.10)$ & $0.062( \pm 0.02)$ & $12.821( \pm 2.21)$ & $9.49( \pm 0.31)$ \\
\hline MAGNOLONA & $10.08( \pm 0.02)$ & $0.152( \pm 0.04)$ & $22.983( \pm 2.87)$ & $8.41( \pm 0.03)$ \\
\hline MONTEDORO & $4.2( \pm 0.21)$ & $0.06( \pm 0.02)$ & $10.574( \pm 0.64)$ & $14.87( \pm 0.47)$ \\
\hline NONNO & $5.24( \pm 0.16)$ & $0.089( \pm 0.08)$ & $17.173( \pm 2.90)$ & $8.14( \pm 0.45)$ \\
\hline PANZONA & $3.56( \pm 0.35)$ & $0.314( \pm 0.04)$ & $9.142( \pm 0.92)$ & $17.14( \pm 0.09)$ \\
\hline PAOLONA & $4.20( \pm 0.19)$ & $0.271( \pm 0.07)$ & $11.281( \pm 1.55)$ & $12.27( \pm 0.15)$ \\
\hline PAZZA & $4.25( \pm 0.19)$ & $0.147( \pm 0.03)$ & $20.753( \pm 2.89)$ & $10.12( \pm 0.33)$ \\
\hline POLLASTRELLA & $4.86( \pm 0.12)$ & $0.134( \pm 0.05)$ & $7.532( \pm 1.78)$ & $13.49( \pm 0.25)$ \\
\hline PUZO & $3.59( \pm 0.20)$ & $0.057( \pm 0.02)$ & $17.433( \pm 2.86)$ & $11.52( \pm 0.41)$ \\
\hline $\begin{array}{c}\text { SAN } \\
\text { FRANCESCO }\end{array}$ & $5.64( \pm 0.33)$ & $0.092( \pm 0.02)$ & $27.879( \pm 0.79)$ & $6.88( \pm 0.22)$ \\
\hline SCASSULILLO & $8.92( \pm 0.17)$ & $0.114( \pm 0.02)$ & $8.303( \pm 2.65)$ & $10.58( \pm 0.23)$ \\
\hline $\begin{array}{l}\text { SCASSULILLO } \\
\text { GRANDE }\end{array}$ & $9.85( \pm 0.24)$ & $0.100( \pm 0.03)$ & $24.424( \pm 3.87)$ & $8.42( \pm 0.13)$ \\
\hline SIGNORA & $3.47( \pm 0.26)$ & $0.208( \pm 0.03)$ & $17.075( \pm 7.73)$ & $9.26( \pm 0.10)$ \\
\hline ZEPPONA & $4.86( \pm 0.12)$ & $0.112( \pm 0.05)$ & $26.329( \pm 11.60)$ & $7.62( \pm 0.08)$ \\
\hline tipo 35 & $4.42( \pm 0.43)$ & $0.194( \pm 0.03)$ & $13.789( \pm 3.53)$ & $8.98( \pm 0.23)$ \\
\hline
\end{tabular}

\section{2. $\beta$-Carotene Content}

For some years, the nutritional importance of carotenoids has been related to their capacity to act as a precursor of vitamin A, retinol. Such a peculiarity is essential and is typical of $\beta$-carotene, greatly helpful for our body, to supply a quantity of $1 \mathrm{mg}$, we need $6 \mathrm{mg}$ of $\beta$-carotene, on the other hand, for all other carotenoids, and such rate is 12:1 (https: / / www.inran.it/carotenoidi/8708/ accessed on 10 September 2021). The content of $\beta$-carotene found in our samples was very variable depending on variety (Table 1 ). Some of them exhibited an amount of $\beta$-carotene ("Puzo", "Montedoro" and "Lisandrina", "Fracasso", "Fronne"," Nonno" and "San Francesco") not exceeding $0.1 \mathrm{mg} 100 \mathrm{~g}^{-1}$ of fresh weight; other varieties showed a content of $\beta$-carotene never lower than $0.2 \mathrm{mg} 100 \mathrm{~g}^{-1}$ of fresh weight. Three of them, "Baracca", Panzona, and the "Boccuccia Eboli" showed no less than $0.3 \mathrm{mg} 100 \mathrm{~g}^{-1}$ of fresh weight; the variety "Baracca" variety arrived to exceed $0.4 \mathrm{mg}$ 
$100 \mathrm{~g}^{-1}$ of fresh weight, and resulted perfectly in line with the values reported by the Italian Council for the research in agriculture and analysis of agricultural economy (http:/ / nut. entecra.it/646/tabelle_di_composizione_degli_alimenti.html?idalimento $=007000$ accessed on 5 November 2021). In addition, the four varieties "Boccuccia" ("Eboli", "Grossa", "Liscia", and "Spinosa") showed different results, with "Boccuccia spinosa" exhibiting the lowest amount of $\beta$-carotene $\left(0.134 \mathrm{mg} 100 \mathrm{~g}^{-1}\right.$ of fresh weight), less than half if compared with the variety "Boccuccia Eboli", which had $0.307 \mathrm{mg} 100 \mathrm{~g}^{-1}$ of fresh weight. Such values were lower than those reported by Leccese et al. [31] on different Italian varieties of apricot, including "Boccuccia spinosa", even if such varieties were cultivated in a different territory and probably collected in 2010, so, with diverse geographic, soil and climate situation. In any case, some of the varieties analyzed, such as "Paolona"," Panzona", three among the four varieties "Boccuccia" ("Eboli", "Grossa" and "Liscia"), and variety "Signora" possessed a content of $\beta$-carotene undoubtedly superior to the apricot "tipo 35" used as control. Some of the varieties we analyzed showed a level of $\beta$-carotene superior to those grown in China and characterized by Zhou et al. [32], and some Moroccan varieties analyzed by Ayour et al. [33]. This could indicate that the amount of $\beta$-carotene could depend not only on the variety but also on the cultivation area (with variables including climate) and the year of cultivation.

\subsection{Total Polyphenols Content}

Polyphenols constitute one of the principal founts of antioxidant activity. The quality and nutritional features of fruit and vegetables are affected by several parameters, such as the environment, and the cultivation practices [34]. Climate, light intensity, temperature, and the water accessibility can influence their antioxidant activity too, as well as their polyphenol content $[35,36]$. Phenolic compounds are vital for the plant tissue, as they are involved in the plant defense mechanism, through the prevention of pathogen growth, also by strengthening the vegetal tissues [37]. From a biological point of view, one of their most important roles is their antioxidant activity [38]. The amount of total polyphenols (TPs) also appeared very variable among the varieties analyzed. Many of them had a TPs content higher than that exhibited by the "tipo 35" that we used as a control. In some cases, the TPs content was also double ("San Francesco"), 2.17 times higher ("Baracca") and it even reached 2.5 times greater ("Boccuccia Eboli") than the control. Some varieties, such as "Fronne Fresche", "Panzona", "Pollastrella", and "Scassulillo" had a TPs content of less than $10 \mathrm{mg} .100 \mathrm{~g}^{-1}$ of fresh weight. Furthermore, about total polyphenols, the group of varieties "Boccuccia" showed a not completely uniform behavior, with three of the varieties ("Boccuccia Grossa", "Boccuccia Liscia" and "Boccuccia spinosa") which contained a practically similar quantity of TPs. The exception was represented by the "Boccuccia Eboli" which, with $35.875 \mathrm{mg} 100 \mathrm{~g}^{-1}$ of fresh weight, was also the variety with the highest TPs content. Our data resulted superior to those obtained by Nourazi et al. [30] on the Iranian variety "Nouri", whose TP content did not exceed about $4.3 \mathrm{mg}$ $100 \mathrm{~g}^{-1}$ of fresh weight. The content of total polyphenols exhibited by the variety "Boccuccia Eboli" was very similar to that contained in the variety "Neraida" [29], and in the variety Nostos [39]. Therefore, the content of total polyphenols of the variety "Baracca" was similar to the variety "Nereis" [39].

\subsection{Antioxidant Activity}

The antioxidant activity exhibited by the apricot varieties was calculated by means of the DPPH test, and expressed in terms of EC50, indicating the quantity, in $\mathrm{mg}$, of the extract, necessary to inhibit the activity of $1 \mathrm{~mL}$ of the DPPH radical by $50 \%$ The data are shown in Table 1. In general, we observed that, except some varieties, in particular "Pollastrella" (EC50 = $13.49 \mathrm{mg})$, "Montedoro" (EC50 = $14.87 \mathrm{mg})$, and "Panzona" $(\mathrm{EC} 50=17.14 \mathrm{mg})$-this last exhibiting the weakest antioxidant activity - the other varieties showed EC50 values never exceeding $13 \mathrm{mg}$, and, for many of them, it was fewer than $9.0 \mathrm{mg}$. "Zeppona" (EC50 = $7.62 \mathrm{mg}$ ), "Campana" (EC50 = $7.46 \mathrm{mg})$, but above all "San 
Francesco" (EC50 = $6.88 \mathrm{mg})$ and "Boccuccia Eboli" $(6.60 \mathrm{mg})$, exhibited the best antioxidant performances. All the varieties possessed antioxidant activity higher than that of "Halman" one, which EC50 was of about $46.6 \mathrm{mg} / \mathrm{mL} \mathrm{DPPH} \mathrm{[40],} \mathrm{or,} \mathrm{considering} \mathrm{the} \mathrm{difference}$ between fresh and dried product, also respect to that showed by commercial dried apricot analyzed by Canadanovic-Brunet et al. [41], or a commercial apricot bought in a local market in Algeria [42]. The capacity of apricot to exert a good antioxidant activity is of particular relevance. Apricots can ameliorate the inflammatory cell infiltration, epithelial desquamation, and microvillar damage occurring in the intestines of rats [43], and, from tests performed on rats, they could show a preventive effect, if regularly consumed, on oxidative stress due to ethanol, also limiting the subsequent histopathological changes [44].

Using the unweighted average Euclidean distance, we have hierarchically clustered data considering the normalized content of $\beta$-carotene, total polyphenols normalized content, and ascorbic acid normalized content. Results are shown in Figure 1.

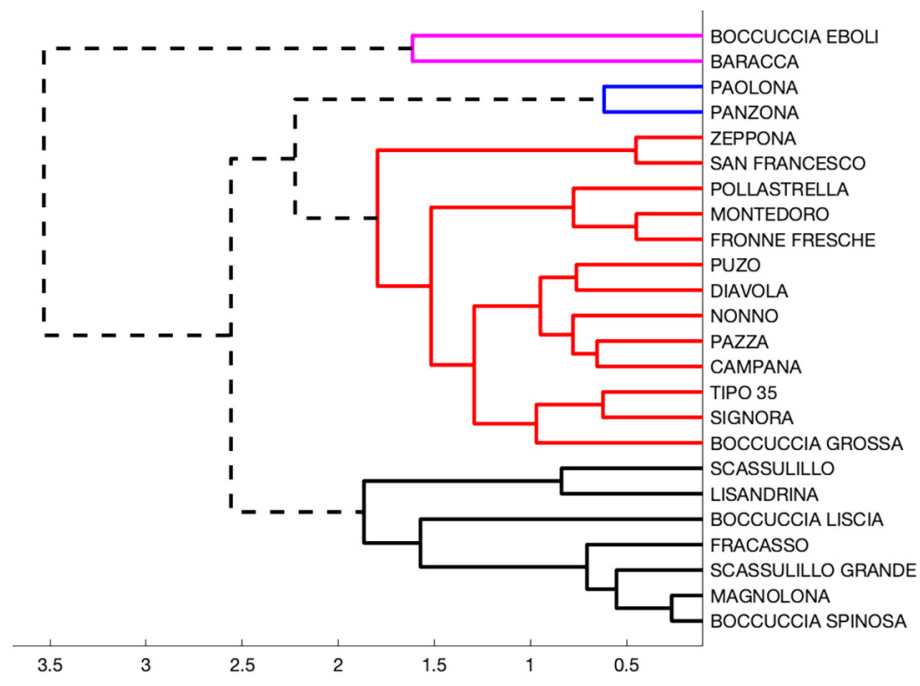

Figure 1. Hierarchical clustering of varieties obtained using a Euclidean unweighted distance and considering the normalized content of $\beta$-carotene, total polyphenols normalized content, and ascorbic acid normalized content. We used 1.9 as the cutoff distance.

We could identify four groups considering 1.9 as cutoff distance (1.9 is approximatively equal to half of the largest distance between clusters). For the most populated groups (the black and the red ones), we then analyzed the correlation among the antioxidant activity, the ascorbic acid content, and the total polyphenols content. Varieties in the black group ("Scassulillo", "Lisandrina", "Boccuccia Liscia", "Fracasso", "Scassulillo Grande", "Magnolona", and "Boccuccia spinosa") showed a high correlation between ascorbic acid content and the antioxidant activity $(-0.89)$, while the correlation with the content of total polyphenols was lower $(-0.45)$. For this group, our results can thus agree with ErdoganOrhan and Kartal [15], for whom the polyphenolic fraction did not show a significant scavenging activity against DPPH, while it exerted a moderate scavenging effect against superoxide anion at $156 \mathrm{mg} \mathrm{mL}^{-1}$. However, our results are in disagreement with Ishiwata et al. [45], which found high correlation between the DPPH radical scavenging activity and polyphenols content. The antioxidant activity of varieties in the red group, on the contrary, showed a higher correlation with the content of total polyphenols $(-0.67)$, respect to that with the content of ascorbic acid (-0.55), confirming, albeit partially, the influence that polyphenols can exert on the antioxidant activity. No group shows an appreciable correlation between antioxidant activity and $\beta$-carotene content.

\subsection{Polyphenol Profile}

Polyphenol profile is generally dependent on the genetic variation and the geographical conditions present at the time of the vegetable growth. Thus, a major number of 
information is welcome to identify the best varieties within a species that, for their quality and nutritional value can represent a given area. As far as we know, no studies are reporting the biochemical characterization of a so considerable number of varieties of apricot, traditional of the Campania regions, including polyphenols profile, obtained through UPLC. All data are shown in Table 2 and are indicated as $\mu \mathrm{g} \mathrm{g}^{-1}$.

UPLC analysis -based on known molecules- recognized chlorogenic acid the most abundant phenolic acid. Its content ranged between $9.94 \mu \mathrm{g} \mathrm{g}^{-1} \mathrm{FW}$ and $55.07 \mu \mathrm{g} \mathrm{g}^{-1}$ of fresh weight. High values of such molecule were observed in the cultivars "Baracca" and "Boccuccia di Eboli" (55.07 and $53.40 \mu \mathrm{g} \mathrm{g}^{-1}$ of fresh weight, respectively). The other three "Boccuccia" varieties, that is "Grossa", "Liscia" and "Spinosa" showed just lower content of this molecule, in any case never inferior to $46.50 \mathrm{\mu g} \mathrm{g}^{-1}$ of fresh weight. Our data agree with Gottingerova et al. [46], which found the content of chlorogenic acid ranging

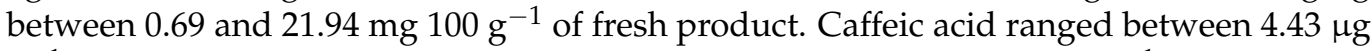
$\mathrm{g}^{-1}$ of fresh weight (found in the cultivar "Pollastrella") and $38.77 \mu \mathrm{g} \mathrm{g}^{-1}$ (exhibited by cultivar "San Francesco"). Similarly, the content of gallic acid showed variability, ranging from $4.18 \mu \mathrm{g} \mathrm{g}^{-1}$ (in the variety "Signora") to $11.70 \mu \mathrm{g} \mathrm{g}^{-1}$ of fresh weight (in the variety "Baracca"). P-coumaric and ferulic acids, the other two phenolic acids identified by UPLC did not exceed $6.34 \mu \mathrm{g} \mathrm{g}^{-1}$ and $11.07 \mu \mathrm{g} \mathrm{g}^{-1}$, respectively, both in the variety "Boccuccia grossa". Catechin, epicatechin, and rutin resulted from the most predominant flavonoids recognized by UPLC-DAD, agreeing with Gundogdu et al. [47]. Catechin, in particular, resulted particularly abundant. Once again, "Baracca" and "Boccuccia di Eboli" showed the highest content of catechin $\left(89.66 \mu \mathrm{g} \mathrm{g}^{-1}\right.$ and $96.15 \mu \mathrm{g} \mathrm{g}^{-1}$, respectively); similarly, the other cultivar of the group "Boccuccia" exhibited a similar amount of the molecule, which ranged from $50.16 \mu \mathrm{g} \mathrm{g}^{-1}$ ("Boccuccia grossa") to $52.14 \mathrm{\mu g} \mathrm{g}^{-1}$ ("Boccuccia spinosa"). "San Francesco" showed a high amount of caffeic acid and catechin, resulting from the cultivar with the highest content of epicatechin $\left(49.03 \mu \mathrm{g} \mathrm{g}^{-1}\right)$. The presence of a significant quantity of catechin and epicatechin in several of these apricot varieties represents an undoubted point of interest from human health. Catechins are recognized to decrease the hazard of some diseases. They can lead to the control of lipid and glucose/insulin metabolism [48]; they also have positive effects on the eye [49], nervous system, [50], and heart [51], and can exert anti-inflammatory effects [52] too. The molecule may also exhibit antibacterial and anti-biofilm activity $[53,54]$. Epicatechin and its metabolites may boost the muscle performance, act on the symptoms of cardiovascular and cerebrovascular diseases, and support human health, through actions of diabetes prevention and protection of the nervous system [55]. Rutin, which occurrence in the diet with vitamin $C$ helps in the control of the fast blood glucose [56], was abundant in the "Boccuccia di Eboli" (53.76 $\mu \mathrm{g}$ $\left.\mathrm{g}^{-1}\right)$, "Scassulillo grande" (45.95 $\left.\mathrm{\mu g} \mathrm{g}^{-1}\right)$, "San Francesco" $\left(42.94 \mu \mathrm{g} \mathrm{g}^{-1}\right)$, and "Baracca" $\left(39.54 \mu \mathrm{g} \mathrm{g}^{-1}\right)$. "B. grossa" and "B. spinosa" exhibited rutin content ranging between $19.92 \mu \mathrm{g} \mathrm{g}^{-1}$, and $24.76 \mu \mathrm{g} \mathrm{g}^{-1}$, respectively. The "Scassulillo" group of apricots, composed on "Scassulillo" and "Scassulillo grande" showed only as regard caffeic acid a similar trend. In all the other cases, the content of the singular polyphenols was higher in the cultivar "S. grande" than in "Scassulillo" Luteolin was detected only in traces and not in all cultivars. Quercetin and apigenin were usually undetected. They were present only in the cultivar "Baracca" and "Boccuccia di Eboli"; on the other hand, cultivar "Campana" showed traces also of quercetin. The almost complete absence of quercetin was once again in agreement with Iglesias-Carres et al., [57] and Gottingerova et al. [46], which detected this flavonoid only in one of the cultivars they analyzed ("Sefora") and in traces. 
Table 2. Amount of polyphenols known present in the varieties of Campania apricots, detected by UPLC-DAD. Data are reported as $\mu \mathrm{g} \mathrm{g}^{-1}$ of fresh product and are mean values $\pm \mathrm{SD}$ of three determinations. QUE: quercetin; CAF: caffeic acid; GAL: gallic acid; CHLO: chlorogenic acid; CAT: catechin; EPIC:e picatechin; COUM: $p$-coumaric acid; RUT: rutin; FER: ferulic acid; LUT: luteolin; API: apigenin.

\begin{tabular}{|c|c|c|c|c|c|c|c|c|c|c|c|}
\hline & 孚 & 岁 & 选 & $\stackrel{\circ}{\stackrel{\Xi}{\vec{J}}}$ & 它 & 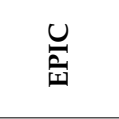 & $\sum_{0}$ & 占 & 䓢 & S & 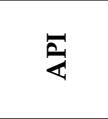 \\
\hline Baracca & $\begin{array}{c}0.286 \\
( \pm 0.03)\end{array}$ & $\begin{array}{c}8.77 \\
( \pm 0.65)\end{array}$ & $\begin{array}{c}11.70 \\
( \pm 0.91\end{array}$ & $\begin{array}{c}55.07 \\
( \pm 4.24)\end{array}$ & $\begin{array}{c}89.66 \\
( \pm 6.54)\end{array}$ & $\begin{array}{c}36.34 \\
( \pm 3.27)\end{array}$ & $\begin{array}{c}1.81 \\
( \pm 0.04)\end{array}$ & $\begin{array}{c}39.54 \\
( \pm 3.74)\end{array}$ & $\begin{array}{c}4.44 \\
( \pm 0.57)\end{array}$ & $\begin{array}{c}0.00 \\
( \pm 0.00)\end{array}$ & $\begin{array}{c}0.24 \\
( \pm 0.01)\end{array}$ \\
\hline $\begin{array}{l}\text { Boccuccia } \\
\text { Eboli }\end{array}$ & $\begin{array}{c}1.83 \\
( \pm 0.05)\end{array}$ & $\begin{array}{c}27.16 \\
( \pm 1.67)\end{array}$ & $\begin{array}{c}8.45 \\
( \pm 1.13)\end{array}$ & $\begin{array}{c}53.40 \\
( \pm 2.67)\end{array}$ & $\begin{array}{c}96.15 \\
( \pm 4.37)\end{array}$ & $\begin{array}{c}40.88 \\
( \pm 3.33)\end{array}$ & $\begin{array}{c}4.69 \\
( \pm 0.73)\end{array}$ & $\begin{array}{c}53.76 \\
( \pm 4.57)\end{array}$ & $\begin{array}{c}7.78 \\
( \pm 0.64)\end{array}$ & $\begin{array}{c}4.75 \\
( \pm 0.21)\end{array}$ & $\begin{array}{c}2.27 \\
( \pm 0.14)\end{array}$ \\
\hline $\begin{array}{c}\text { Boccuccia } \\
\text { Grossa }\end{array}$ & $\begin{array}{c}0.00 \\
( \pm 0.00)\end{array}$ & $\begin{array}{c}13.97 \\
( \pm 1.13)\end{array}$ & $\begin{array}{c}6.30 \\
( \pm 0.57)\end{array}$ & $\begin{array}{c}46.50 \\
( \pm 4.67)\end{array}$ & $\begin{array}{c}50.16 \\
( \pm 4.67)\end{array}$ & $\begin{array}{c}28.09 \\
( \pm 1.57)\end{array}$ & $\begin{array}{c}6.34 \\
( \pm 0.23)\end{array}$ & $\begin{array}{c}19.92 \\
( \pm 1.23)\end{array}$ & $\begin{array}{c}11.07 \\
( \pm 1.02)\end{array}$ & $\begin{array}{c}2.70 \\
( \pm 0.97)\end{array}$ & $\begin{array}{c}0.00 \\
( \pm 0.00)\end{array}$ \\
\hline $\begin{array}{l}\text { Boccuccia } \\
\text { Liscia }\end{array}$ & $\begin{array}{c}0.00 \\
( \pm 0.00)\end{array}$ & $\begin{array}{c}20.26 \\
( \pm 1.57)\end{array}$ & $\begin{array}{c}7.29 \\
( \pm 1.23)\end{array}$ & $\begin{array}{c}48.12 \\
( \pm 2.67)\end{array}$ & $\begin{array}{c}51.39 \\
( \pm 2.67)\end{array}$ & $\begin{array}{c}30.31 \\
( \pm 3.09)\end{array}$ & $\begin{array}{c}3.84 \\
( \pm 0.44)\end{array}$ & $\begin{array}{c}20.86 \\
( \pm 1.13)\end{array}$ & $\begin{array}{c}5.71 \\
( \pm 0.94)\end{array}$ & $\begin{array}{c}2.14 \\
( \pm 0.07)\end{array}$ & $\begin{array}{c}0.00 \\
( \pm 0.00)\end{array}$ \\
\hline Campana & $\begin{array}{c}2.82 \\
( \pm 0.03)\end{array}$ & $\begin{array}{c}9.98 \\
( \pm 1.12) \\
\end{array}$ & $\begin{array}{c}5.34 \\
( \pm 1.07)\end{array}$ & $\begin{array}{c}34.87 \\
( \pm 3.47)\end{array}$ & $\begin{array}{c}55.64 \\
( \pm 3.35)\end{array}$ & $\begin{array}{c}32.41 \\
( \pm 4.04)\end{array}$ & $\begin{array}{c}1.93 \\
( \pm 0.06)\end{array}$ & $\begin{array}{c}22.26 \\
( \pm 1.66)\end{array}$ & $\begin{array}{c}2.78 \\
( \pm 0.67)\end{array}$ & $\begin{array}{c}0.00 \\
( \pm 0.00)\end{array}$ & $\begin{array}{c}0.00 \\
( \pm 0.00)\end{array}$ \\
\hline Diavola & $\begin{array}{c}0.00 \\
( \pm 0.00)\end{array}$ & $\begin{array}{c}9.69 \\
( \pm 0.57)\end{array}$ & $\begin{array}{c}7.71 \\
( \pm 1.44)\end{array}$ & $\begin{array}{c}32.33 \\
( \pm 2.67)\end{array}$ & $\begin{array}{c}42.88 \\
( \pm 1.57)\end{array}$ & $\begin{array}{c}18.47 \\
( \pm 1.57)\end{array}$ & $\begin{array}{c}2.64 \\
( \pm 023)\end{array}$ & $\begin{array}{c}23.42 \\
( \pm 0.03)\end{array}$ & $\begin{array}{c}3.36 \\
( \pm 0.03)\end{array}$ & $\begin{array}{c}0.45 \\
( \pm 0.05)\end{array}$ & $\begin{array}{c}0.00 \\
( \pm 0.00)\end{array}$ \\
\hline Fracasso & $\begin{array}{c}0.00 \\
( \pm 0.00)\end{array}$ & $\begin{array}{c}15.80 \\
( \pm 0.57)\end{array}$ & $\begin{array}{c}8.00 \\
( \pm 1.23)\end{array}$ & $\begin{array}{c}38.18 \\
( \pm 2.12)\end{array}$ & $\begin{array}{c}42.63 \\
( \pm 3.44) \\
\end{array}$ & $\begin{array}{c}11.17 \\
( \pm 0.97)\end{array}$ & $\begin{array}{c}2.09 \\
( \pm 0.21)\end{array}$ & $\begin{array}{c}42.89 \\
( \pm 1.67)\end{array}$ & $\begin{array}{c}6.34 \\
( \pm 1.12)\end{array}$ & $\begin{array}{c}2.99 \\
( \pm 0.45)\end{array}$ & $\begin{array}{c}0.00 \\
( \pm 0.00)\end{array}$ \\
\hline $\begin{array}{l}\text { Fronne } \\
\text { Fresche }\end{array}$ & $\begin{array}{c}0.00 \\
( \pm 0.00)\end{array}$ & $\begin{array}{c}2.46 \\
( \pm 0.43) \\
\end{array}$ & $\begin{array}{c}4.51 \\
( \pm 1.05) \\
\end{array}$ & $\begin{array}{c}20.09 \\
( \pm 1.54) \\
\end{array}$ & $\begin{array}{c}19.52 \\
( \pm 1.47) \\
\end{array}$ & $\begin{array}{c}7.19 \\
( \pm 1.02) \\
\end{array}$ & $\begin{array}{c}0.82 \\
( \pm 0.04) \\
\end{array}$ & $\begin{array}{c}26.19 \\
( \pm 2.01)\end{array}$ & $\begin{array}{c}1.42 \\
( \pm 0.22)\end{array}$ & $\begin{array}{c}2.39 \\
( \pm 0.37) \\
\end{array}$ & $\begin{array}{c}0.00 \\
( \pm 0.00)\end{array}$ \\
\hline Lisandrina & $\begin{array}{c}0.00 \\
( \pm 0.00)\end{array}$ & $\begin{array}{c}11.08 \\
( \pm 0.84) \\
\end{array}$ & $\begin{array}{c}5.14 \\
( \pm 0.63) \\
\end{array}$ & $\begin{array}{c}14.24 \\
( \pm 1.02)\end{array}$ & $\begin{array}{c}49.29 \\
( \pm 2.04) \\
\end{array}$ & $\begin{array}{c}12.57 \\
( \pm 1.02)\end{array}$ & $\begin{array}{c}2.44 \\
( \pm 0.14) \\
\end{array}$ & $\begin{array}{c}9.62 \\
( \pm 0.67) \\
\end{array}$ & $\begin{array}{c}1.89 \\
( \pm 0.57) \\
\end{array}$ & $\begin{array}{c}2.69 \\
( \pm 0.08) \\
\end{array}$ & $\begin{array}{c}0.00 \\
( \pm 0.00)\end{array}$ \\
\hline Magnolona & $\begin{array}{c}0.00 \\
( \pm 0.00)\end{array}$ & $\begin{array}{c}11.21 \\
( \pm 1.04)\end{array}$ & $\begin{array}{c}7.02 \\
( \pm 0.97) \\
\end{array}$ & $\begin{array}{c}40.76 \\
( \pm 1.33) \\
\end{array}$ & $\begin{array}{c}51.17 \\
( \pm 2.04) \\
\end{array}$ & $\begin{array}{c}42.02 \\
( \pm 1.44) \\
\end{array}$ & $\begin{array}{c}2.80 \\
( \pm 0.73) \\
\end{array}$ & $\begin{array}{c}31.49 \\
( \pm 2.67) \\
\end{array}$ & $\begin{array}{c}2.30 \\
( \pm 0.13)\end{array}$ & $\begin{array}{c}1.51 \\
( \pm 0.12)\end{array}$ & $\begin{array}{c}0.00 \\
( \pm 0.00)\end{array}$ \\
\hline Montedoro & $\begin{array}{c}0.00 \\
( \pm 0.00)\end{array}$ & $\begin{array}{c}10.50 \\
( \pm 1.34) \\
\end{array}$ & $\begin{array}{c}6.39 \\
( \pm 0.37) \\
\end{array}$ & $\begin{array}{c}29.97 \\
( \pm 2.67) \\
\end{array}$ & $\begin{array}{c}17.20 \\
( \pm 1.57) \\
\end{array}$ & $\begin{array}{c}8.06 \\
( \pm 1.36) \\
\end{array}$ & $\begin{array}{c}0.80 \\
( \pm 0.04) \\
\end{array}$ & $\begin{array}{c}15.47 \\
( \pm 1.03)\end{array}$ & $\begin{array}{c}1.93 \\
( \pm 0.21) \\
\end{array}$ & $\begin{array}{c}0.00 \\
( \pm 0.00)\end{array}$ & $\begin{array}{c}0.00 \\
( \pm 0.00)\end{array}$ \\
\hline Nonno & $\begin{array}{c}0.00 \\
( \pm 0.00) \\
\end{array}$ & $\begin{array}{c}9.83 \\
( \pm 0.57) \\
\end{array}$ & $\begin{array}{c}4.66 \\
( \pm 0.57) \\
\end{array}$ & $\begin{array}{c}42.55 \\
( \pm 1.15) \\
\end{array}$ & $\begin{array}{c}38.62 \\
( \pm 1.67) \\
\end{array}$ & $\begin{array}{c}19.61 \\
( \pm 1.33) \\
\end{array}$ & $\begin{array}{c}1.13 \\
( \pm 0.08) \\
\end{array}$ & $\begin{array}{c}24.15 \\
( \pm 1.05) \\
\end{array}$ & $\begin{array}{c}2.72 \\
( \pm 0.14) \\
\end{array}$ & $\begin{array}{c}3.25 \\
( \pm 0.45) \\
\end{array}$ & $\begin{array}{c}0.00 \\
( \pm 0.00) \\
\end{array}$ \\
\hline Panzona & $\begin{array}{c}0.00 \\
( \pm 0.00) \\
\end{array}$ & $\begin{array}{c}2.86 \\
( \pm 0.44) \\
\end{array}$ & $\begin{array}{c}5.38 \\
( \pm 0.52)\end{array}$ & $\begin{array}{c}17.01 \\
( \pm 1.23)\end{array}$ & $\begin{array}{c}13.00 \\
( \pm 1.44)\end{array}$ & $\begin{array}{c}16.93 \\
( \pm 1.06)\end{array}$ & $\begin{array}{c}1.25 \\
( \pm 0.15)\end{array}$ & $\begin{array}{c}19.19 \\
( \pm 0.81)\end{array}$ & $\begin{array}{c}0.83 \\
( \pm 0.03)\end{array}$ & $\begin{array}{c}1.07 \\
( \pm 0.02)\end{array}$ & $\begin{array}{c}0.00 \\
( \pm 0.00)\end{array}$ \\
\hline Paolona & $\begin{array}{c}0.00 \\
( \pm 0.00) \\
\end{array}$ & $\begin{array}{c}7.96 \\
( \pm 0.70) \\
\end{array}$ & $\begin{array}{c}5.75 \\
( \pm 0.12) \\
\end{array}$ & $\begin{array}{c}22.12 \\
( \pm 1.44) \\
\end{array}$ & $\begin{array}{c}28.09 \\
( \pm 1.67) \\
\end{array}$ & $\begin{array}{c}8.30 \\
( \pm 0.74) \\
\end{array}$ & $\begin{array}{c}1.97 \\
( \pm 0.12) \\
\end{array}$ & $\begin{array}{c}25.16 \\
( \pm 1.67) \\
\end{array}$ & $\begin{array}{c}1.33 \\
( \pm 0.02) \\
\end{array}$ & $\begin{array}{c}3.51 \\
( \pm 0.43) \\
\end{array}$ & $\begin{array}{c}0.00 \\
( \pm 0.00)\end{array}$ \\
\hline Pazza & $\begin{array}{c}0.00 \\
( \pm 0.00)\end{array}$ & $\begin{array}{c}10.59 \\
( \pm 0.77)\end{array}$ & $\begin{array}{c}10.36 \\
( \pm 0.57)\end{array}$ & $\begin{array}{c}14.73 \\
( \pm 0.67)\end{array}$ & $\begin{array}{c}77.50 \\
( \pm 2.67)\end{array}$ & $\begin{array}{c}16.68 \\
( \pm 1.23)\end{array}$ & $\begin{array}{c}3.89 \\
( \pm 0.73)\end{array}$ & $\begin{array}{c}32.77 \\
( \pm 1.52)\end{array}$ & $\begin{array}{c}2.59 \\
( \pm 0.08)\end{array}$ & $\begin{array}{c}5.91 \\
( \pm 0.57)\end{array}$ & $\begin{array}{c}0.00 \\
( \pm 0.00)\end{array}$ \\
\hline Puzo & $\begin{array}{c}0.00 \\
( \pm 0.00)\end{array}$ & $\begin{array}{c}12.84 \\
( \pm 0.62) \\
\end{array}$ & $\begin{array}{c}6.76 \\
( \pm 0.14)\end{array}$ & $\begin{array}{c}33.29 \\
( \pm 2.23)\end{array}$ & $\begin{array}{c}47.12 \\
( \pm 2.54)\end{array}$ & $\begin{array}{c}21.36 \\
( \pm 1.57)\end{array}$ & $\begin{array}{c}1.87 \\
( \pm 0.54)\end{array}$ & $\begin{array}{c}17.76 \\
( \pm 1.24)\end{array}$ & $\begin{array}{c}3.17 \\
( \pm 1.04)\end{array}$ & $\begin{array}{c}2.50 \\
( \pm 0.15)\end{array}$ & $\begin{array}{c}0.00 \\
( \pm 0.00)\end{array}$ \\
\hline $\begin{array}{c}\text { San } \\
\text { Francesco }\end{array}$ & $\begin{array}{c}0.00 \\
( \pm 0.00) \\
\end{array}$ & $\begin{array}{c}38.77 \\
( \pm 2.04) \\
\end{array}$ & $\begin{array}{c}7.24 \\
( \pm 1.07)\end{array}$ & $\begin{array}{c}22.26 \\
( \pm 1.57)\end{array}$ & $\begin{array}{c}65.55 \\
( \pm 2.06) \\
\end{array}$ & $\begin{array}{c}49.03 \\
( \pm 1.52)\end{array}$ & $\begin{array}{c}4.83 \\
( \pm 1.04)\end{array}$ & $\begin{array}{c}42.94 \\
( \pm 2.67)\end{array}$ & $\begin{array}{c}1.77 \\
( \pm 0.12)\end{array}$ & $\begin{array}{c}2.61 \\
( \pm 0.15)\end{array}$ & $\begin{array}{c}0.00 \\
( \pm 0.00)\end{array}$ \\
\hline Scassulillo & $\begin{array}{c}0.00 \\
( \pm 0.00)\end{array}$ & $\begin{array}{c}5.64 \\
( \pm 0.03)\end{array}$ & $\begin{array}{c}5.83 \\
( \pm 0.03)\end{array}$ & $\begin{array}{c}15.28 \\
( \pm 0.03)\end{array}$ & $\begin{array}{c}24.04 \\
( \pm 0.03)\end{array}$ & $\begin{array}{c}9.34 \\
( \pm 0.03)\end{array}$ & $\begin{array}{c}1.16 \\
( \pm 0.03)\end{array}$ & $\begin{array}{c}7.55 \\
( \pm 0.03)\end{array}$ & $\begin{array}{c}1.26 \\
( \pm 0.03)\end{array}$ & $\begin{array}{c}0.31 \\
( \pm 0.08)\end{array}$ & $\begin{array}{c}0.00 \\
( \pm 0.03)\end{array}$ \\
\hline $\begin{array}{l}\text { Scassulillo } \\
\text { Grande }\end{array}$ & $\begin{array}{c}0.00 \\
( \pm 0.00)\end{array}$ & $\begin{array}{c}12.28 \\
( \pm 0.81)\end{array}$ & $\begin{array}{c}11.52 \\
( \pm 1.03)\end{array}$ & $\begin{array}{c}32.61 \\
( \pm 0.45)\end{array}$ & $\begin{array}{c}60.56 \\
( \pm 3.06)\end{array}$ & $\begin{array}{c}38.76 \\
( \pm 2.67)\end{array}$ & $\begin{array}{c}3.34 \\
( \pm 1.13)\end{array}$ & $\begin{array}{c}45.95 \\
( \pm 2.55)\end{array}$ & $\begin{array}{c}2.84 \\
( \pm 0.12)\end{array}$ & $\begin{array}{c}0.00 \\
( \pm 0.00)\end{array}$ & $\begin{array}{c}0.00 \\
( \pm 0.00)\end{array}$ \\
\hline Signora & $\begin{array}{c}0.00 \\
( \pm 0.00)\end{array}$ & $\begin{array}{c}13.81 \\
( \pm 0.84)\end{array}$ & $\begin{array}{c}4.18 \\
( \pm 0.12)\end{array}$ & $\begin{array}{c}28.69 \\
( \pm 1.21)\end{array}$ & $\begin{array}{c}54.92 \\
( \pm 3.67)\end{array}$ & $\begin{array}{c}11.7 \\
( \pm 0.89)\end{array}$ & $\begin{array}{c}1.61 \\
( \pm 0.04)\end{array}$ & $\begin{array}{c}27.39 \\
( \pm 2.02)\end{array}$ & $\begin{array}{c}1.76 \\
( \pm 0.02)\end{array}$ & $\begin{array}{c}0.59 \\
( \pm 0.03)\end{array}$ & $\begin{array}{c}0.00 \\
( \pm 0.00)\end{array}$ \\
\hline Zeppona & $\begin{array}{c}0.00 \\
( \pm 0.00)\end{array}$ & $\begin{array}{c}20.43 \\
( \pm 1.67)\end{array}$ & $\begin{array}{c}8.19 \\
( \pm 0.62)\end{array}$ & $\begin{array}{c}30.09 \\
( \pm 2.14)\end{array}$ & $\begin{array}{c}78.96 \\
( \pm 2.67)\end{array}$ & $\begin{array}{c}48.02 \\
( \pm 1.57)\end{array}$ & $\begin{array}{c}2.66 \\
( \pm 0.05)\end{array}$ & $\begin{array}{c}30.32 \\
( \pm 2.05)\end{array}$ & $\begin{array}{c}2.91 \\
( \pm 0.16)\end{array}$ & $\begin{array}{c}1.93 \\
( \pm 0.02)\end{array}$ & $\begin{array}{c}0.00 \\
( \pm 0.00)\end{array}$ \\
\hline Pollastrella & $\begin{array}{c}0.00 \\
( \pm 0.00)\end{array}$ & $\begin{array}{c}4.43 \\
( \pm 0.57)\end{array}$ & $\begin{array}{c}4.00 \\
( \pm 0.67)\end{array}$ & $\begin{array}{c}9.94 \\
( \pm 1.01)\end{array}$ & $\begin{array}{c}16.75 \\
( \pm 1.57)\end{array}$ & $\begin{array}{c}13.73 \\
( \pm 1.23)\end{array}$ & $\begin{array}{c}1.36 \\
( \pm 0.16)\end{array}$ & $\begin{array}{c}12.55 \\
( \pm 1.15)\end{array}$ & $\begin{array}{c}1.15 \\
( \pm 0.05)\end{array}$ & $\begin{array}{c}0.00 \\
( \pm 0.00)\end{array}$ & $\begin{array}{c}0.00 \\
( \pm 0.00)\end{array}$ \\
\hline $\begin{array}{l}\text { Boccuccia } \\
\text { Spinosa }\end{array}$ & $\begin{array}{c}0.00 \\
( \pm 0.00)\end{array}$ & $\begin{array}{c}12.54 \\
( \pm 1.02)\end{array}$ & $\begin{array}{c}7.03 \\
( \pm 0.21)\end{array}$ & $\begin{array}{c}48.45 \\
( \pm 2.57)\end{array}$ & $\begin{array}{c}52.14 \\
( \pm 2.23)\end{array}$ & $\begin{array}{c}24.72 \\
( \pm 1.57)\end{array}$ & $\begin{array}{c}2.17 \\
( \pm 0.04)\end{array}$ & $\begin{array}{c}26.76 \\
( \pm 1.54)\end{array}$ & $\begin{array}{c}6.94 \\
( \pm 0.32)\end{array}$ & $\begin{array}{c}4.47 \\
( \pm 0.21)\end{array}$ & $\begin{array}{c}0.00 \\
( \pm 0.00)\end{array}$ \\
\hline Tipo 35 & $\begin{array}{c}0.00 \\
( \pm 0.00)\end{array}$ & $\begin{array}{c}13.51 \\
( \pm 1.02)\end{array}$ & $\begin{array}{c}5.32 \\
( \pm 0.87)\end{array}$ & $\begin{array}{c}11.62 \\
( \pm 0.97)\end{array}$ & $\begin{array}{c}39.92 \\
( \pm 2.05)\end{array}$ & $\begin{array}{c}11.28 \\
( \pm 0.84)\end{array}$ & $\begin{array}{c}1.74 \\
( \pm 0.04)\end{array}$ & $\begin{array}{c}28.95 \\
( \pm 2.23)\end{array}$ & $\begin{array}{c}2.43 \\
( \pm 0.04)\end{array}$ & $\begin{array}{c}2.91 \\
( \pm 0.03)\end{array}$ & $\begin{array}{c}0.00 \\
( \pm 0.00)\end{array}$ \\
\hline
\end{tabular}


We have also considered all the available data (gallic acid, caffeic acid, chlorogenic acid, ferulic acid, $p$-coumaric acid, rutin, catechin, epicatechin, luteolin, ascorbic acid, $\beta$-carotene, total polyphenols, and antioxidant activity) and, after normalizing the data (in percentage, compared to the control "tipo 35") we have performed a PCA (after data standardization).

Results (regarding the first two components) are shown in the Figure 2, where, for readability, we used separate symbols with a specific color (red, black, pink, and blue, full or empty) assigned to the varieties. In such a way, we represented each point with a symbol whose color is the group color to which the data point belongs (according to the dendrogram shown in Figure 1). Data points still can be considered as clustered according to the already introduced groups.

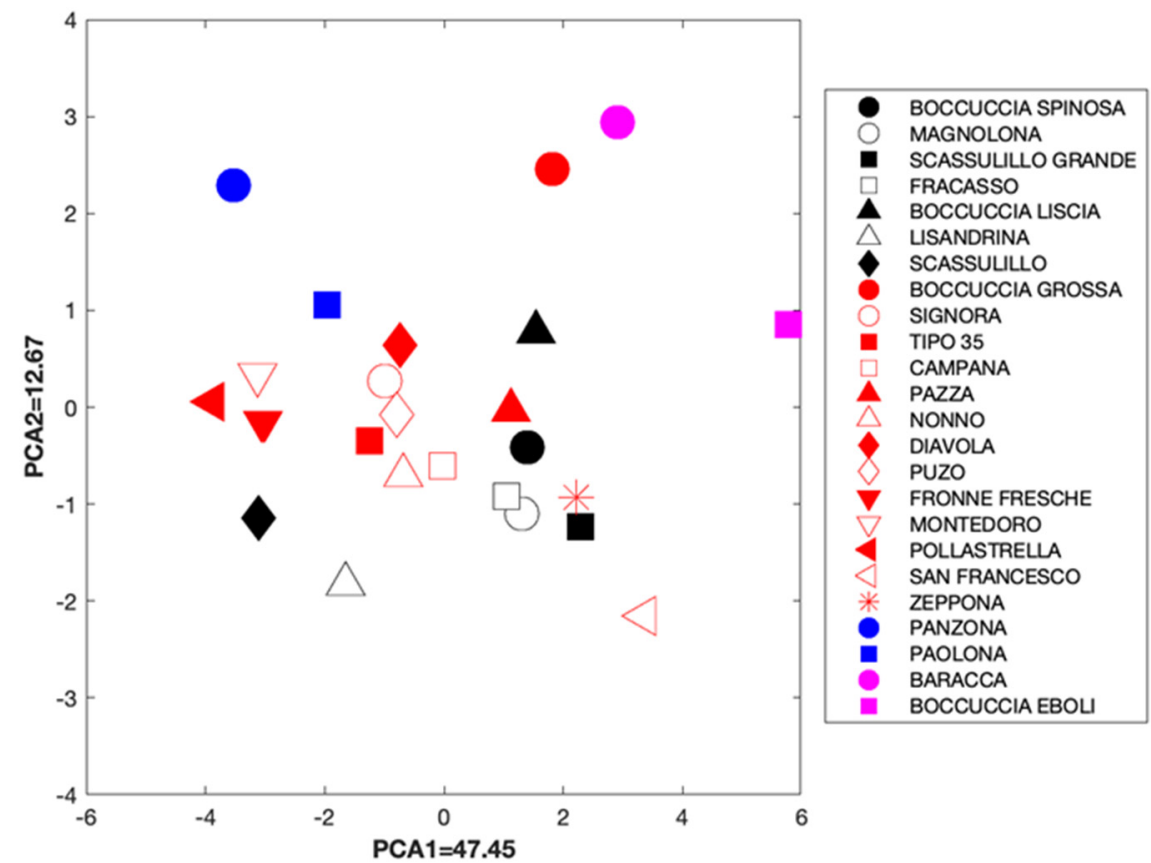

Figure 2. Varieties plotted using the first two PCA components and considering all the available (standardized) data.

Thus, while taking into account that clustering may not be very evident, given, for example, the overlapping between the groups indicated by the colors red and black, the presence of two majority clusters could certainly be confirmed. The most abundant cluster was composed of 13 varieties (indicated by red colors, with full and empty symbols, including that "type 35" that was used as control); the second cluster comprised seven varieties (marked by full and empty black symbols). Two varieties, "Pazza" and "Zeppona", indicated with red symbols, seemed very close to the black-symbolized "B. spinosa" and "S. grande" varieties. Two other pairs of varieties, "Panzona" and "Paolona" on one side, and "Baracca" and "Boccucia Eboli" on the other (indicated by solid blue and pink symbols, respectively), appeared to form two small groups apart. On the contrary, the "Magnolona" and "Fracasso" varieties were superimposable. From the clustering point of view, "Campana" and "Signora" varieties were also very close to each other too.

\section{Conclusions}

The valorization of fruit and vegetables representing a specific territory and community might be strategic to meet the key thoughts of the market and satisfy the growing need of the consumers to preserve their cultural traditions. Campania region represent one of the richest regions in Italy in terms of vegetal biodiversity, unfortunately not yet valorized in an adequate way, also outside its territory. Therefore, the Campania region is one of the most dynamic regions for the safeguard and valorization of the own vegetal genetic resource. As far as one can tell, this is the first time that a similar study regarded different 
traditional varieties of Campania apricots, grown and collected at the same conditions and in the same period, respectively, to counteract those variables capable of influencing their metabolic pathway. Our results suggest that such varieties can have great potential due to the content of phytochemicals useful for human health, compared to the control. The data obtained could contribute to the improvement of cultivation programs to safeguard the autochthonous biodiversity, considering consumers' health. Finally, we should not forget that encouraging farmers to grow native fruit and vegetable varieties could also lead to an increase in their income.

Author Contributions: Conceptualization, F.F. and F.N.; investigation, F.F., F.N., A.d., D.A. and M.D.M.; methodology, F.F., A.d., R.C. and F.N.; software, A.d.; supervision, F.N.; writing-original draft, F.N. and A.d.; writing-review and editing, F.N. and D.A. All authors have read and agreed to the published version of the manuscript.

Funding: The work was partially supported by the Campania regional Projects "Safeguarding the Genetic Plant Biodiversity of Campania Region (SALVE)" and "Network for the safeguard and management of agro-food genetic resources of the Campania Region (AGRIGENET)" PSR 2007-2013, az. f2.

Acknowledgments: The authors are really grateful to Clemente Meccariello, Luigi Cipriano and Filomeno Canonico for their technical support.

Conflicts of Interest: The authors declare no conflict of interest.

\section{References}

1. Hormaza, J.I.; Yamane, H.; Rodrigo, J. Apricot. In Genome Mapping and Molecular Breeding in Plants; Kole, C., Ed.; Fruits and Nuts; Springer: Berlin/Heidelberg, Germany, 2007; Volume 4, pp. 171-187.

2. Gatti, E.; Defilippi, B.G.; Predieri, S.; Infante, R. Apricot (Prunus armeniaca L.) quality and breeding perspectives. J. Food Agric. Environ. 2009, 7, 573-580.

3. Glisic, I.; Milosevic, T.; Milosevic, N.; Nikolic, R.; Paunovic, G. Agroeconomic analysis of apricot production in early years after planting. In Book of Proceedings: Fifth International Scientific Agricultural Symposium "Agrosym 2014"; University of East Sarajevo, Faculty of Agriculture: Lukavica, Republika Srpska, 2014; pp. 215-220.

4. Fratianni, F.; d'Acierno, A.; Cipriano, L.; Nazzaro, F. Apricots: Biochemistry and functional properties. Curr. Opin. Food Sci. 2018, 19, 23-29. [CrossRef]

5. Sharma, R.; Gupta, A.; Abrol, G.S.; Joshi, V.K. Value addition of wild apricot fruits grown in North-West Himalayan regions. J. Food Sci. Technol. 2014, 51, 2917-2924. [CrossRef]

6. Leccese, A.; Bartolini, S.; Viti, R. Total antioxidant capacity and phenolics content in fresh apricots. Acta Aliment. 2008, 37, 65-76. [CrossRef]

7. Gecer, M.K.; Kan, T.; Gundogdu, M.; Ercisli, S.; Ilhan, G.; Sagbas, H.I. Physicochemical characteristics of wild and cultivated apricots (Prunus armeniaca L.) from Aras valley in Turkey. Genet. Resour. Crop Evol. 2020, 67, 935-945. [CrossRef]

8. Rashid, F.; Ahmed, R.; Mahmood, A.; Ahmad, Z.; Bib, P.N.; Urooj Kazm, S.U. Flavonoid glycosides from Prunus armeniaca and the antibacterial activity of a crude extract. Arch. Pharmacal Res. 2007, 30, 932-937. [CrossRef]

9. Minaiyan, M.; Ghannadi, A.; Asadi, M.; Etemad, M.; Mahzouni, P. Antiinflammatory effect of Prunus armeniaca L. (Apricot) extracts ameliorates TNBS-induced ulcerative colitis in rats. Res. Pharm. Sci. 2014, 9, 225-231. [PubMed]

10. Jaafar, H.J. Effects of Apricot and Apricot Kernels on Human Health and Nutrition: A Review of Recent Human Research. Tech. BioChemMed 2021, 2, 139-162. [CrossRef]

11. Garcia-Gomez, B.E.; Ruiz, D.; Salazar, J.A.; Rubio, M.; Martinez-Garcia, P.J.; Martinez Gomez, P. Analysis of Metabolites and Gene Expression Changes Relative to Apricot (Prunus armeniaca L.) Fruit Quality During Development and Ripening. Front. Plant Sci. 2020, 11, 1-24. [CrossRef] [PubMed]

12. Alajil, O.; Sagar, V.R.; Kaur, C.; Rudra, S.G.; Sharma, R.R.; Kaushik, R.; Verma, M.K.; Tomar, M.; Kumar, M.; Mekhemar, M. Nutritional and Phytochemical Traits of Apricots (Prunus armeniaca L.) for Application in Nutraceutical and Health Industry. Foods 2021, 10, 1344. [CrossRef]

13. Perez-Jimenez, J.; Neveu, V.; Vos, F.; Scalbert, A. Identification of the 100 richest dietary sources of polyphenols: An application of the Phenol-Explorer database. Eur. J. Clin. Nutr. 2010, 64, S112-S120. [CrossRef]

14. Wani, S.M.; Masoodi, F.A.; Wani, T.A.; Ahmad, M.; Gani, A.; Ganai, S.A. Physical characteristics, mineral analysis and antioxidant properties of some apricot varieties grown in North India. COG Food Agric. 2015, 1, 1-10. [CrossRef]

15. Erdogan-Orhan, I.; Kartal, M. Insights into research on phytochemistry and biological activities of Prunus armeniaca L. (apricot). Food Res. Int. 2011, 44, 1238-1243. [CrossRef] 
16. Nazzaro, F.; Caliendo, G.; Arnesi, G.; Veronesi, A.; Sarzi, P.; Fratianni, F. Comparative content of some bioactive compounds in two varieties of Capsicum annuum L. Sweet pepper and evaluation of their antimicrobial and mutagenic activities. J. Food Biochem. 2009, 33, 852-868. [CrossRef]

17. Fratianni, F.; d'Acierno, A.; Cozzolino, A.; Spigno, P.; Riccardi, R.; Raimo, F.; Pane, C.; Zaccardelli, M.; Tranchida Lombardo, V.; Tucci, M.; et al. Biochemical Characterization of Traditional Varieties of Sweet Pepper (Capsicum annuum L.) of the Campania Region, Southern Italy. Antioxidants 2020, 9, 556. [CrossRef] [PubMed]

18. Fratianni, F.; Cozzolino, A.; d'Acierno, A.; Nazzaro, F.; Riccardi, R.; Spigno, P. Qualitative Aspects of Some Traditional Landraces of the Tomato "Piennolo" (Solanum lycopersicum L.) of the Campania Region, Southern Italy. Antioxidants 2020, 9, 565. [CrossRef] [PubMed]

19. Singleton, V.L.; Rossi, J.A. Colorimetry of Total Phenolics with Phosphomolybdic Phosphotungstic Acid Reagents. Am. J. Enol. Vitic. 1965, 16, 144-158.

20. Ombra, M.N.; d'Acierno, A.; Nazzaro, F.; Riccardi, R.; Spigno, P.; Zaccardelli, M.; Pane, C.; Maione, M.; Fratianni, F. Phenolic composition and antioxidant and antiproliferative activities of the extracts of twelve common bean (Phaseolus vulgaris L.) endemic ecotypes of Southern Italy before and after cooking. Oxiddative Med. Cell. Longev. 2016, 2016, 1398298. [CrossRef] [PubMed]

21. Pane, C.; Fratianni, F.; Parisi, M.; Nazzaro, F.; Zaccardelli, M. Control of Alternaria post-harvest infections on cherry tomato fruits by wild pepper phenolic-rich extracts. Crop Prot. 2016, 84, 81-87. [CrossRef]

22. Wani, S.M.; Riyaz, U.; Wani, T.A.; Ahmad, M.; Gani, A.; Masoodi, F.A.; Dar, B.N.; Nazir, S.A. Mir, S.A. Influence of processing on physicochemical and antioxidant properties of Apricot (Prunus armeniaca L. variety Narmo. Cogent Food Agric. $2016,2,1176287$.

23. Ishaq, A.; Rathore, H.A.; Masud, T.; Ali, S. Influence of post harvest calcium chloride application, ethylene absorbent and modified atmosphere on quality characteristics and shelf life of apricot (Prunus armeniaca L.) fruit during storage. Pak. J. Nutr. 2009, 8, 861-865. [CrossRef]

24. Hegedus, A.; Engel, R.; Abranko, L.; Balogh, E.; Blazovics, A.; Herman, R.; Halasz, J.; Ercisli, S.; Pedryc, A.; Stefanovits-Banyai, E. Antioxidant and Antiradical Capacities in Apricot (Prunus armeniaca L.) Fruits: Variations from Genotypes, Years, and Analytical Methods. J. Food Sci. 2010, 75, C722-C730. [CrossRef] [PubMed]

25. Akin, E.B.; Karabulut, I.; Topcu, A. Some compositional properties of main Malatya apricot (Prunus armeniaca L.) varieties. Food Chem. 2008, 107, 939-948. [CrossRef]

26. Derardja, A.; Pretzler, M.; Kampatsikas, I.; Barkat, M.; Rompel, A. Inhibition of apricot polyphenol oxidase by combinations of plant proteases and ascorbic acid. Food Chem. X 2019, 4, 100053. [CrossRef]

27. Cui, K.; Zhao, H.; Sun, L.; Yang, L.; Cao, J.; Jiang, W. Impact of near freezing temperature storage on post harvest quality and antioxidant capacity of two apricots (Prunus armeniaca L.). J. Food Biochem. 2019, 43, e12857. [CrossRef]

28. Wani, S.M.; Hussain, P.R.; Masoodi, F.A.; Ahmad, M.; Wani, T.A.; Gani, A.; Rather, S.A.; Suradkar, P. Evaluation of the Composition of Bioactive Compounds and Antioxidant Activity in Fourteen Apricot Varieties of North India. J. Agric. Sci. 2017, 9, 66-82. [CrossRef]

29. Kafkaletou, M.; Kalantzis, I.; Karantzi, A.; Christopoulos, M.V.; Tsantili, E. Phytochemical characterization in traditional and modern apricot (Prunus armeniaca L.) cultivars-Nutritional value and its relation to origin. Sci. Hortic. 2019, 253, 195-202. [CrossRef]

30. Nourozi, F.; Sayyari, M. Enrichment of Aloe vera gel with basil seed mucilage preserves bioactive compounds and postharvest quality of apricot fruits. Sci. Hortic. 2020, 262, 109041. [CrossRef]

31. Leccese, A.; Viti, R.; Bartolini, S. The effect of solvent extraction on antioxidant properties of apricot fruit. Cent. Eur. J. Biol. 2011, 6 , 199-204. [CrossRef]

32. Zhou, W.; Niu, Y.; Ding, X.; Zhao, S.; Lia, Y.; Fan, G.; Zhang, S.; Liao, K. Analysis of carotenoid content and diversity in apricots (Prunus armeniaca L.) grown in China. Food Chem. 2020, 330, 127223. [CrossRef]

33. Ayour, J.; Sagar, M.; Alfeddy, M.N.; Taourirte, M.; Benichou, M. Evolution of pigments and their relationship with skin color based on ripening in fruits of different Moroccan genotypes of apricots (Prunus armeniaca L.). Sci. Hortic. 2016, 207, 168-175. [CrossRef]

34. Bennett, L.E.; Jegasothy, H.; Konczak, I.; Frank, D.; Sudharmarajan, S.; Clingeleffer, P.R. Total polyphenolics and anti-oxidant properties of selected dried fruits and relationships to drying conditions. J. Funct. Foods 2011, 3, 115-124. [CrossRef]

35. Pék, Z.; Szuvandzsiev, P.; Daood, H.; Neményi, A.; Helyes, L. Effect of irrigation on yield parameters and antioxidant profiles of processing cherry tomato. Cent. Eur. J. Biol. 2014, 9, 383-395. [CrossRef]

36. Dragovic-Uzelac, V.; Levaj, B.; Mrkic, V.; Bursac, D.; Boras, M. The content of polyphenols and carotenoids in three apricot cultivars depends on the stage of maturity and geographical region. Food Chem. 2007, 102, 966-975. [CrossRef]

37. Rupinder, S.; Smita, R.N.D.U. Phenylpropanoid metabolism in ripening fruits. Compr. Rev. Food Sci. Food Saf. 2010, 9, 398-416.

38. Wang, H.; Cao, G.; Prior, R.L. Total antioxidant capacity of citrus. J. Agric. Food Chem. 1996, 44, 701-705. [CrossRef]

39. Drogoudi, P.D.; Vemmos, S.; Pantelidis, G.; Petri, E.; Tzoutzoukou, C.; Karayiannis, I. Physical characters and antioxidant, sugar, and mineral nutrient contents in fruit from 29 apricot (Prunus armeniaca L.) cultivars and hybrids. J. Agric. Food Chem. 2008, 56, 10754-10760. [CrossRef]

40. Hussain, P.R.; Chatterjee, S.; Variyar, P.S.; Sharma, A.; Dar, M.A.; Wani, A.M. Bioactive compounds and antioxidant activity of gamma-irradiated sun-dried apricots (Prunus armeniaca L.). J. Food Comp. Anal. 2013, 30, 59-66. [CrossRef] 
41. Čanadanović-Brunet, J.M.; Vulić, J.J.; Ćetković, G.S.; Djilas, S.M.; Tumbas-Šaponjac, V.T. Bioactive compounds and antioxidant properties of dried apricot. Acta Period. Technol. 2013, 44, 193-205. [CrossRef]

42. Djenidi, H.; Khennouf, S.; Bouaziz, A. Antioxidant activity and phenolic content of commonly consumed fruits and vegetables in Algeria. Prog. Nutr. 2020, 22, 224-235. [CrossRef]

43. Vardi, N.; Parlakpinar, H.; Ozturk, F.; Ates, B.; Gul, M.; Cetin, A.; Erdogan, A.; Otlu, A. Potent protective effect of apricot and $\beta$-carotene on methotrexate-induced intestinal oxidative damage in rats. Food Chem. Toxicol. 2008, 46, 3015-3022. [CrossRef]

44. Ugras, M.Y.; Kurus, M.; Ates, B.; Soylemez, H.; Otlu, A.; Yilmaz, A. Prunus armeniaca L. (apricot) protects rat testes from detrimental effects of low-dose x-rays. Nutr. Res. 2010, 30, 200-208. [CrossRef]

45. Ishiwata, K.; Yamaguchi, T.; Takamura, H.; Matoba, T. DPPH radical-scavenging activity and polyphenol content in dried fruits. Food Sci. Technol. Res. 2004, 10, 152-156. [CrossRef]

46. Göttingerová, M.; Kumšta, M.; Rampáčková, E.; Kiss, T.; Nečas, T. Analysis of phenolic compounds and some important analytical properties in selected apricot genotypes. Hortiscience 2021, 56, 1-7. [CrossRef]

47. Gundogdu, M.; Ercisli, S.; Berk, S.; Kan, T.; Canan, I.; Gecer, M.K. Diversity on color and phenolic compounds in apricot fruits. J. Food Meas. Charact. 2017, 11, 2087-2093. [CrossRef]

48. Spínola, V.; Pinto, J.; Llorent-Martínez, E.J.; Tomas, H.; Castilho, P.C. Evaluation of Rubus grandifolius L.(wild blackberries) activities targeting management of type-2 diabetes and obesity using in vitro models. Food Chem. Toxicol. 2019, 123, 443-452. [CrossRef]

49. Moine, E.; Brabet, P.; Guillou, L.; Durand, T.; Vercauteren, J.; Crauste, C. New lipophenol antioxidants reduce oxidative damage in retina pigment epithelial cells. Antioxidants 2018, 7, 197. [CrossRef]

50. Ortiz López, L.; Márquez Valadez, B.; Gómez Sánchez, A.; Silva-Lucero, M.D.C.; Ortiz-López, L.; Márquez-Valadez, B.; GómezSánchez, A. Green tea compound epigallo cathechin 3 gallate (EGCG) increases neuronal survival in adult hippocampal neurogenesis in vivo and in vitro. Neuroscience 2016, 322, 208-220. [CrossRef]

51. Oyama, J.; Shiraki, A.; Nishikido, T.; Maeda, T.; Komoda, H.; Shimizu, T.; Makino, N.; Node, K. EGCG, a green tea catechin, attenuates the progression of heart failure induced by the heart/muscle specific deletion of MnSOD in mice. J. Cardiol. 2017, 69, 417-427. [CrossRef]

52. Kapoor, M.P.; Sugita, M.; Nishimura, A.; Sudo, S.; Okubo, T. Influence of acute ingestion and regular intake of green tea catechins on resting oxidative stress biomarkers assays in a paralleled randomized controlled crossover supplementation study in healthy men. J. Funct. Foods 2018, 45, 381-391. [CrossRef]

53. Nazzaro, F.; Fratianni, F.; Cozzolino, R.; Martignetti, A.; Malorni, L.; De Feo, V.; Cruz, A.G.; d'Acierno, A. Antibacterial activity of three extra virgin olive oils of the Campania region, Southern Italy, related to their polyphenol content and composition. Microorganisms 2019, 7, 321. [CrossRef]

54. Liu, L.; Xiao, X.; Li, K.; Li, X.; Shi, B.; Liao, X. Synthesis of catechin rare earth complex with efficient and broad spectrum anti biofilm activity. Chem. Biodivers. 2020, 17, e1900734. [CrossRef]

55. Qu, Z.; Liu, A.; Li, P.; Liu, C.; Xiao, W.; Huang, J.; Liu, Z.; Zhang, S. Advances in physiological functions and mechanisms of (-)-epicatechin. Crit. Rev. Food Sci. Nutr. 2020, 61, 211-233. [CrossRef] [PubMed]

56. Ragheb, S.R.; Mohamed, L.; El Wakeel, L.M.; Nasr, M.S.; Sabri, N.A. Impact of rutin and vitamin C combination on oxidative stress and glycemic control in patients with type 2 diabetes. Clin. Nutr. ESPEN 2020, 35, 128-135. [CrossRef] [PubMed]

57. Iglesias-Carres, L.; Mas-Capdevila, A.; Bravo, F.I.; Bladé, C.; Arola-Arnal, A.; Muguerza, B. Optimization of extraction methods for characterization of phenolic compounds in apricot fruit (Prunus armeniaca). Food Funct. 2019, 10, 6492-6502. [CrossRef] [PubMed] 